\title{
Analysis of thermo-physiological comfort properties of $100 \%$ acrylic, acrylic/cotton, acrylic/viscose and acrylic/PES blended woven fabrics
}

DOI: $10.35530 / I T .070 .04 .1546$

ARZU YAVAŞCAOĞLU

RECEP EREN

GÜLCAN SÜLE

\section{REZUMAT - ABSTRACT}

Analiza proprietăților de confort termofiziologic ale țesăturilor $100 \%$ acrilice și în amestec acril/bumbac, acril/viscoză și acril/PES

În acest studiu s-au investigat proprietățile de confort termofiziologic ale țesăturilor produse cu fir de bătătură 100\% acril, bumbac, viscoză și PES, precum și în amestec acril/PES, actil/bumbac și acril/viscoză. În acest scop, 35 de țesături diferite au fost realizate din fire acrilice în urzeală și fire de bătătură din acril, bumbac, PES, viscoză, acril/bumbac, acril/viscoză și acril/PES, cu trei desimi diferite de bătătură și legături pânză, diagonal și atlaz. Analiza rezultatelor a arătat că nu S-a observat efectul naturii firului și al desimii bătăturii asupra rezistenței termice. S-a observant că tipul de legătură a avut un efect asupra rezistenței termice, absorbției termice și permeabilității la aer a țesăturilor. Valorile permeabilității la aer ale țesăturilor cu legătură pânză au fost mai mici decât cele ale țesăturilor cu legăturile diagonal și atlaz. Permeabilitatea la aer a scăzut odată cu creșterea desimii firelor de bătătură. Conform evaluării statistice, tipul de fir sau natura firului a avut un efect semnificativ asupra rezistenței la vapori de apă, în timp ce desimea firelor de bătătură și tipul de legătură nu au înregistrat efecte semnificative.

Cuvinte-cheie: acrilic, țesături, confort termofiziologic, rezistența la vapori de apă, permeabilitatea la aer

\section{Analysis of thermo-physiological comfort properties of $100 \%$ acrylic, acrylic/cotton, acrylic/viscose and acrylic/PES blended woven fabrics}

In this study, thermo-physiological comfort properties of woven fabrics produced with $\% 100$ acrylic, cotton, viscose and PES weft as well as acrylic/PES, acrylic/cotton and acrylic/viscose weft mixing were investigated. For this purpose, 35 different fabrics were woven with acrylic warp and acrylic, cotton, PES, viscose, acrylic/cotton, acrylic/viscose and acrylic/PES weft yarns, with three different weft densities and plain, twill and satin weaves. Analysis of results showed that the effect of yarn material and weft density on thermal resistance was not observed. It was seen that weave type had an effect on thermal resistance, thermal absorbtivity and air permeability of the fabrics. Air permeability values of fabrics woven with plain weave were lower than those of satin and twill weaves. The air permeability decreased when weft density was increased. According to statistical evaluation, yarn type or yarn material had significant effect and weft density and weave had no significant effect on water vapour resistance.

Keywords: acrylic; woven fabrics; thermo-physiological comfort;water vapour resistance; air permeability

\section{INTRODUCTION}

Acrylic yarns are widely used in knitted and upholstery fabrics while they are in limited use in woven outwear fabrics. In this study, the usability of acrylic yarns in fine woven fabrics has been examined by weaving fabrics with acrylic warp and a mixture of cotton, viscose and PES weft yarns with acrylic weft. The effect of yarn material, fabric weave and weft density on the thermo-physiological comfort properties of the fabrics, planned to be used as outwear garment, have been systematically investigated. Literature studies on this subject show that there is no comprehensive study made on the comfort characteristics of acrylic and acrylic blended woven fabrics. Accordingly, it is thought that this study will cover a deficiency in the literature.

Comfort is defined as a feeling of "being pleased", that is caused by psychological and physical harmony between the human body and the environment [1]. Clothing comfort is generally classified into two groups as sensory comfort and thermophysiological comfort [2]. Sensory comfort means the neurological perceptions that felt during the mechanical contact of the textile material with the skin [3]. Thermo-physiological comfort concerns the thermal balance maintaining ability of fabric between the human body and the environment and that includes heat and moisture transfer mechanisms that occur in fabric [2].

Some of the studies, where comfort features of woven fabrics are investigated, are as follows. Thermal and water vapour resistance values of woven and knitted fabrics made from different fibers were investigated and it was found that thermal and water vapour resistances values were sorted from big to small for different blend as PES/Wool, PAC, Cotton, PES [4]. Mechanicaland physiological comfort characteristics of low weight suit fabrics were investigated and fabrics woven by wool, silk, linen and their different blends were used in trials and linen blended fabrics had better mechanical comfort than the others, while 
silk and silk blended fabrics provided a good water vapour permeability due to the fine fiber structure causing a large surface area for moisture adsorption and difusion. In addition, it was determined that the water vapour transmission ability of fabrics produced by single-ply yarns was higher than that of the double-ply yarns [5]. In a study using PES, cotton, polypropylene yarns, 3 different weaves (D 3/1 twill, broken twill and herringbone) and 12 different washing methods, 180 different denim fabric types were produced. Fabrics with polypropylene weft had the highest moisture management capacity and conventional cotton denim type, which was produced by using $100 \%$ cotton, had the minimum moisture management capability. This means that these fabrics can keep the human body warm for a longer time in humid and cold weather. Furthermore, it was stated that the weave structure did not affect the thermophysiological comfort properties [6]. In the study of comfort characteristics of garment fabrics, it was found that finishing applications affected the moisture transmission properties of fabrics. Air permeability decreased as the weft density increased. Weft yarn material, weft density and weft yarn number, weave structure, weight, fabric thickness and finishing substance a statistical effect, at the $\alpha=0.05$ reliability level [7]. In another study where the thermal properties of PES, cotton and cotton/PES mixed garment fabrics were investigated, it was shown that the geometric parameters of the fabric, its thickness and porosity, generally affected the thermal insulation, air permeability and water vapour permeability and the fluid transport capability depended on the fiber composition and $50 \%$ cotton $/ 50 \%$ PES blended fabrics almost resembled $100 \%$ cotton fabric. Cotton fabric's higher performance in this field was caused by tight packing during yarn formation [8]. In a study where fabrics used in the field of sports activities were made of PES yarns or natural and regenerated yarns with different properties. According to air permeability results, fabrics containing PES or viscose yarns regardless of considering mass per unit area or thickness values of the fabrics had good air transfer. Using natural fibres such as cotton decreased air permeability of fabrics under the same conditions [9]. Men's jacket is a garment made by combining fabrics, interlining and lining materials. These materials have their own thermal comfort features. Fabrics, interlinings and linings were tested as triple layer. According to the test results, the increase in the number of layers caused the decrease in air and water vapour permeability, and caused increase in the thermal resistance of the material [10].

\section{MATERIALS AND METHODS}

At the beginning of the study, the fiber content of a total of 400 top garment (shirt/blouse) fabrics from 20 different companies on the market were examined. According to the results, the most used fiber type was founds as $100 \%$ cotton with $38 \%$ ratio. This was followed by $100 \%$ PES with $13 \%$ ratio, $100 \%$ viscose with $14 \%$ and cotton/PES blends with $13 \%$ share. From these results, it has been deemed appropriate to use cotton, viscose and PES fibers together with acrylic in the study. Experimental fabrics used in this study were produced under industrial conditions in Boyteks Textile Inc. which is in Bursa Nilüfer Organize Sanayi region. The type of warp (acrylic), warp density (28 threads/cm) and warp yarn count (295 dtex) remained the same. 295 dtex acrylic, cotton, viscose and PES weft yarns were used in the weft. The technical properties of these fabrics are given in table 1.

Terms such as acrylic/PES, acrylic/cotton and acrylic/ viscose used in table 1 indicate that 1 PES weft is inserted after 1 acrylic weft or 1 cotton weft is inserted after 1 acrylic weft during fabric production. Thus, in these fabrics, it was tried to achieve \%50 acrylic ratio in the weft. Fabrics were produced with three different weft density $(13,15$ and 17 threads/cm) and three different weave types (plain, twill $3 / 2$ and satin 1/4). Acrylic warp yarns were sized by synthetic sizing material (PVA) and were subjected to desizing and washing $\left(60^{\circ} \mathrm{C}\right)$ after weaving. No dyeing and other finishing processes were applied to the experimental fabrics.

Thermal resistance, thermal absorbtivity and thickness values of experimental fabrics were measured by Alambeta device (the contact pressure was 200 $\mathrm{Pa})$.

Alambeta instrument (invented by Lubos Hes) simulates, to some extent, the heat flow q, which takes place from human skin to a fabric during a short initial contact. The main feature is a unique sensor that measures the thermal drop between the surfaces of a very thin nonmetallic plate using a multiple differential micro thermocouple. This sensor is $0.2 \mathrm{~mm}$ thick, and on contact with a subject at a different temperature, reaches the maximum heat flow in 0.2 seconds. Thus, it simulates the human skin, which is approximately $0.5 \mathrm{~mm}$ thick and whose neuron ends, located in the middle, also take $0.1-0.3$ second to reach $\mathrm{q}$ as the heat begins to flow through the contacted subject. Having reached this peak value, the heat flow decreases and then stabilizes within 3-15 seconds. Sample thickness $\mathrm{h}$ is automatically measured under constant pressure, which can be preset from 100 to $1000 \mathrm{~Pa}$. The measuring area is $100 \mathrm{~cm}^{2}$. This equipment tests the objective evaluation of warm-cool feeling properties of fabrics. To simulate the real conditions of warm-cool feeling evaluation, the instrument measuring head is heated to $32^{\circ} \mathrm{C}$, which correspond to the average human skin temperature, while the fabric is kept at the room temperature $22^{\circ} \mathrm{C}$. Similarly, the time constant of the heat flow sensor, which measures directly the heat flow between the automatically moved measuring head and the fabrics, exhibit similar value $(0,07 \mathrm{sec})$, as the human skin. Consequently, the full signal response is achieved within $0.2 \mathrm{sec}$ [11].

Air permeability values were measured by SDL Atlas (Model M 021A) air permeability measuring device (the contact pressure was $100 \mathrm{~Pa}$ ) according to TS 


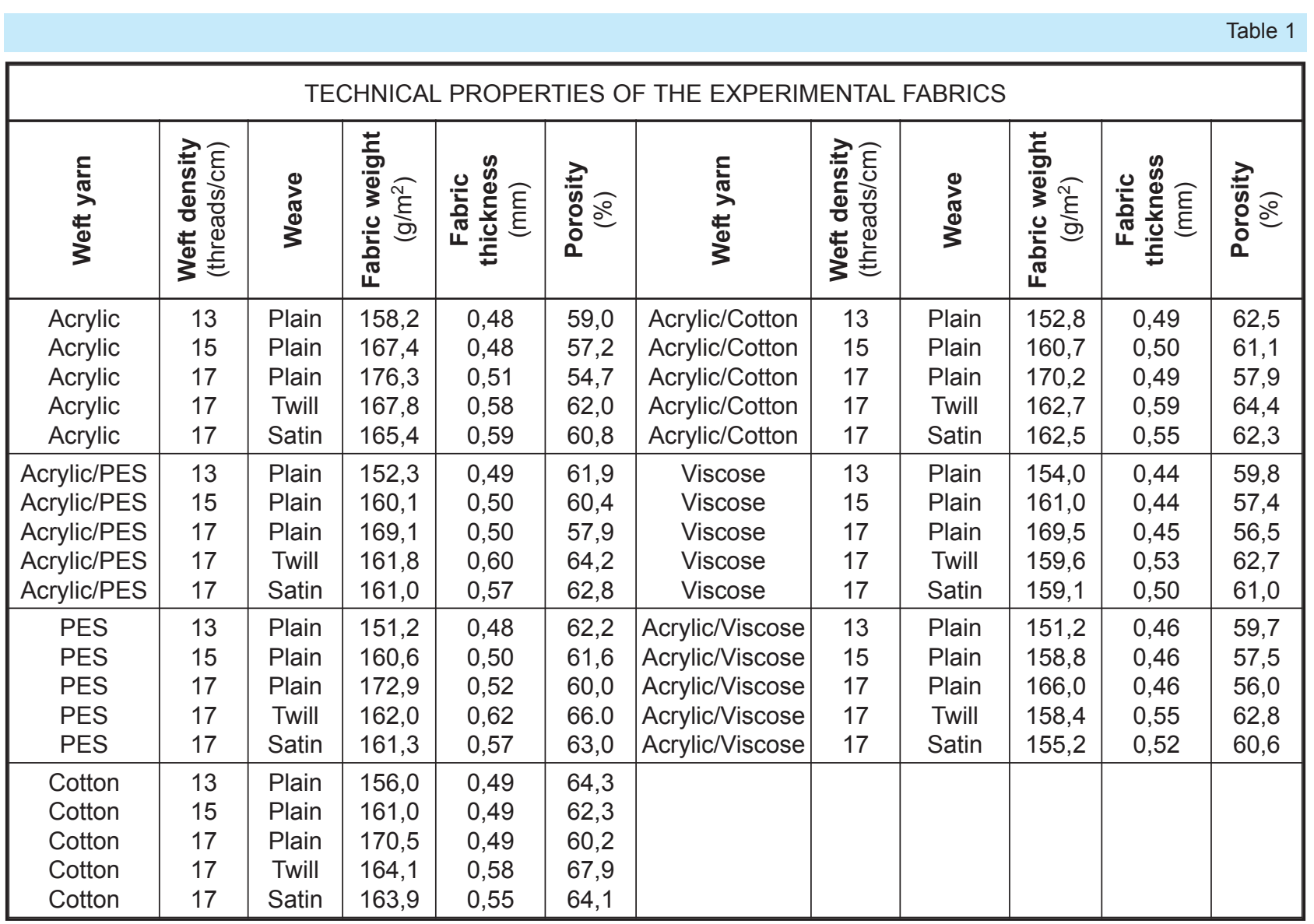

391 EN ISO 9237 standard and the water vapour resistance was measured using Permetest device, according to the ISO EN 11092 standard.

Permetest apparatus (invented by Lubos Hes) measures the amount of heat passing through a thermal model of the human skin. The porous sweating surface of the device simulates the skin and records the cooling heat flow caused by perspiration. The fabric sample to be measured is placed on a measuring head over semi-permeable foil and exposed to parallel air flow at a velocity of $1 \mathrm{~m} / \mathrm{s}$. As with all the skin model systems, the measurements are carried out under isothermal conditions (here $23^{\circ} \mathrm{C}$ ). This isothermal principle involves the temperature of the skin model surface, air temperature and fabric temperature, when the fabric is kept in direct thermal contact with the skin model surface. It does not refer to the fabric surface temperature, when there is an air gap between the skin model surface and the tested fabric. The computer connected to the apparatus determines the evaporative resistance Ret and the thermal resistance Rct of textile fabrics in a similar way to that as well as the RWVP (or relative negative heat flow responsible for the cooling of the body). These values serve to reflect the thermo-physiological properties of textile fabrics and garments. The higher the RWVP, the lower the Ret, and the better the thermal comfort of the garment. Due to the very short measuring time, which normally does not exceed 3 min (the steadystate is indicated by the computer), the fabric mass remains mostly unchanged during the measurements. Fabrics were measured in a laboratory with controlled atmosphere of $21-23^{\circ} \mathrm{C}$ temperature and a $50-55 \%$ relative humidity [12].

In this study, porosity of woven fabrics was calculated using three-dimensional (3-D) unit pore cell models developed by Turan [13] and was given in table 1. Volumetric porosity of fabrics was calculated by Equation 1 and yarn diameter used in this equation was determined using Equation 2 developed by T.F. Peirce [14].

$$
\begin{aligned}
P(\%) & =\frac{p_{1} p_{2} t-\pi / 4\left(d_{1}^{2} l_{1}+d_{2}^{2} l_{2}\right)}{p_{1} p_{2} t} \\
d & =2 \sqrt{\frac{V_{y}}{\pi N 100}}(\mathrm{~cm})
\end{aligned}
$$

where:

$p$ is distance between two yarn centers;

$t$ - fabric thickness;

I - yarn length within the pore cell;

$V_{y}$ - yarn specific volume;

$N$ - metric yarn count;

1 and 2 indices represent warp and weft yarns respectively.

Yarn specific volume is given as $V_{y}=1 /\left(0,59 \rho_{f}\right)$ where 0,59 is packing constant of fibres in the yarn and $\rho_{\mathrm{f}}$ is fibre density.

Effect of fiber type which was used with acrylic yarns, weave type and weft density were evaluated statistically by using SPSS 16 program. Factor analysis of variance (One-Way ANOVA) was performed to examine the effect of the variables and Tukey HSD and 
TAMHANE tests from multiple comparison tests were applied to determine which groups differ statistically from other groups. The $F$ statistic $\left(F_{s}\right)$ values in the analysis of variance were compared with values of $F_{0.05, n, t}$ on the table and the importance of the factor was determined accordingly. Significance level (sig.) was evaluated at $p<0,05$ level.

\section{RESULT AND DISCUSSION}

Thermal resistance $\left(R, m^{2} K / W\right)$ (in stable condition), is a value, which is calculated by dividing the temperature difference between two sections of material and the heat flow rate between the sections and a power which resist against heat transfer. Garments with higher thermal resistance values are preferred for protection from cold, while those with low thermal resistance properties are preferred over hot days [15]. The thermal resistance values of the fabrics are shown in figure 1. According to the measured data, the thermal resistance values of the fabrics vary between 11,4 and $15,6 \mathrm{~m}^{2} \mathrm{~K} / \mathrm{W} \times 10^{-3}$. The highest thermal resistance value was observed on the woven fabric in twill weave with PES weft yarn and in density of 17 threads $/ \mathrm{cm}$. Since the thermal resistance of the fabric is directly proportional to the thickness of the fabric, it is expected that this fabric, which is the thickest fabric among all fabrics, has the highest thermal resistance. In general, when looking at the results, the thermal resistance values of fabrics woven with all types of weft yarns, in three different weft density and plain weave, are close to each other. However, the thermal resistance values of fabrics woven in twill and satin weave are higher than the thermal resistance values of fabrics woven in plain weave. The reason for this is that the fabrics woven in twill and satin weave are thicker than the fabrics woven in plain weave.

When the thermal resistance values of plain weave fabrics which are woven by adding PES, cotton and viscose weft yarns to the acrylic weft yarn are compared with the thermal resistance values of the fabrics woven by $100 \%$ acrylic yarn, the thermal resistance values of these fabrics are close to each other. When the same comparison is made in twill and satin weave fabrics, it is observed that the addition of cotton, PES, and viscose weft to acrylic reduces the thermal resistance of fabrics, especially in satin weave fabrics compared to $100 \%$ acrylic weft fabrics. The reason for this is that the thicknesses of these fabrics are lower than $100 \%$ acrylic weft fabric.

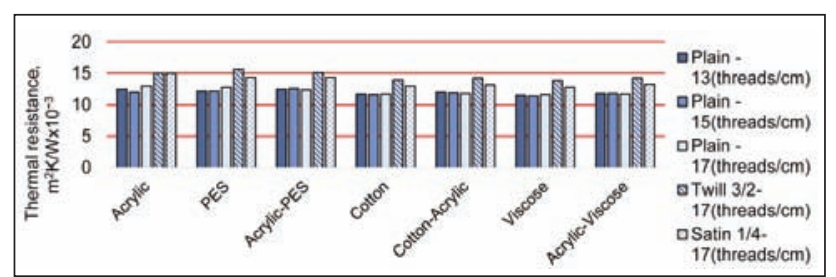

Fig. 1. Thermal resistance values of the fabrics

To statistically examine the effect of weft type, weft density and weave type on the thermal comfort properties of trial fabrics used in the study, One Way Variance Analysis (One-way ANOVA) and Multiple Comparison (Post-Hoc) tests were performed in the SPSS program. Kolmogorov Smirnov (normality) test was performed to determine whether the data provided parametric test conditions. The test result Sig(p) was found to be bigger than 0.05 and the normal distribution was determined. When the equation of error variances (Levene) test variance was not homogenous (Sig. $<0.05)$ in the multiple comparison table; Tamhane and when it was homogeneous (Sig. > 0,05), Tukey HSD test results were evaluated. The results of statistical relation test between weft type, weave type and weft density and variables are given in table 2. The significance level of the relationship between the variables is determined by looking at the significance level (Sig.(p)). A statistically significant relationship is assumed when the Sig.(p) value is less than 0.05 [16]

When the thermal resistance measurement results of the fabrics were evaluated statistically (table 2), it was found that the weave type had an effect on the thermal resistance and the weft type and weft density had no effect on the thermal resistance. According to table 3, when statisticall difference between weave types is examined there is significant difference between plain and twill and satin weave fabrics but no significant difference between twill and satin weave fabrics.

Thermal absorbtivity (b, Ws $1 / 2 / \mathrm{m}^{2} \mathrm{~K}$ ) (temporarily), is the instantaneous heat flow that occurs when two parts at different temperatures come into contact with each other. Thermal absorbtivity means the hot, cold sense of the garment, that is, the first perception sense of the fabric at the first contact. That is the numerical value of the heat transfer rate between the fabric and the skin. If the thermal absorbtivity is low, the fabric feels warm at first contact; If it is high, it

ANALYSIS OF VARIANCE (ANOVA) P-VALUES FOR THERMO-PHYSIOLOGICAL COMFORT PROPERTIES OF THE FABRICS

\begin{tabular}{|l|c|c|c|c|c|c|c|c|}
\hline & \multicolumn{2}{|c|}{ Thermal resistance } & \multicolumn{2}{c|}{ Thermal absorbtivity } & \multicolumn{2}{c|}{ Air permeability } & \multicolumn{2}{c|}{ Water vapour resistance } \\
\cline { 2 - 9 } & $\mathbf{F}$ & Sig. & $\mathbf{F}$ & Sig. & $\mathbf{F}$ & Sig. & $\mathbf{F}$ & Sig. \\
\hline Weft type & 0,955 & 0,473 & 2,462 & 0,49 & 0,331 & 0,915 & 12,903 & 0 \\
\hline Weave & 22,091 & 0 & 13,893 & 0 & 103,786 & 0 & 0,312 & 0,736 \\
\hline Weft density & 0,373 & 0,694 & 2,335 & 0,125 & 27,150 & 0 & 1,066 & 0,365 \\
\hline
\end{tabular}


EFFECT OF WEAVING TYPE ON THERMAL RESISTANCE, THERMAL ABSORBTIVITY AND AIR PERMEABILITY, RESULTS OF THE MULTIPLE COMPARISON (POST-HOC) TESTS

\begin{tabular}{|c|c|c|c|c|c|c|c|c|c|c|c|c|c|c|}
\hline \multicolumn{15}{|c|}{ Multiple comparisons } \\
\hline 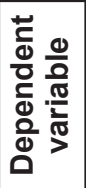 & 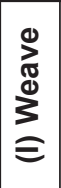 & 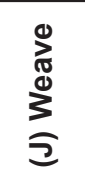 & 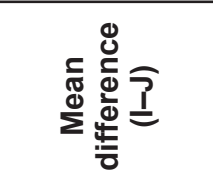 & i் & 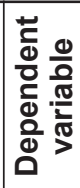 & 音 & 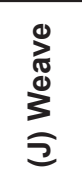 & 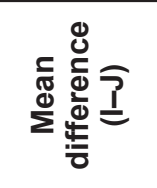 & i் & 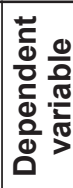 & $\begin{array}{l}0 \\
\substack{\pi \\
ٍ} \\
\vdots\end{array}$ & $\begin{array}{l}\sum_{\pi}^{0} \\
\stackrel{0}{0} \\
3\end{array}$ & 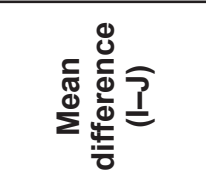 & வ் \\
\hline \multicolumn{15}{|c|}{ Tukey HSD } \\
\hline \multirow{6}{*}{ 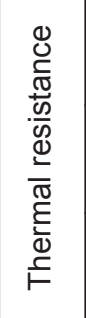 } &.$\subseteq$ & twill & $-2,45714286^{*}$ & 0 & \multirow{6}{*}{ 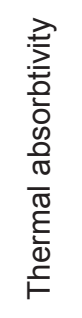 } & \multirow{2}{*}{$\frac{\frac{.}{\pi}}{\frac{\pi}{2}}$} & twill & $20,8571^{*}$ & 0 & \multirow{6}{*}{ 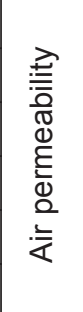 } & \multirow{2}{*}{$\frac{\frac{5}{\pi}}{2}$} & twill & $-225,285714^{*}$ & 0 \\
\hline & $\frac{0}{2}$ & satin & $-1,58571429^{*}$ & 0,001 & & & satin & $15,5714^{*}$ & 0,004 & & & satin & $-261,142857^{*}$ & 0 \\
\hline & \multirow{2}{*}{$\overline{\bar{z}}$} & plain & $2,45714286^{*}$ & 0 & & \multirow{2}{*}{$\overline{\overline{3}}$} & plain & $-20,8571^{*}$ & 0 & & \multirow{2}{*}{$\overline{\overline{3}}$} & plain & $225,285714^{*}$ & 0 \\
\hline & & satin & 0,87142857 & 0,078 & & & satin & $-5,2857$ & 0,421 & & & satin & $-35,857143$ & 0,190 \\
\hline & \multirow{2}{*}{ 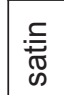 } & plain & $1,58571429^{*}$ & 0,001 & & \multirow{2}{*}{ 离 } & plain & $-15,5714^{*}$ & 0,004 & & \multirow{2}{*}{ 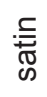 } & plain & $261,142857^{*}$ & 0 \\
\hline & & twill &,- 87142857 & 0,078 & & & twill & 5,2857 & 0,421 & & & twill & 35,857143 & 0,190 \\
\hline
\end{tabular}

gives cold feeling. Especially in cold days, this parameter, which gives the feeling of comfort to the wearer at the time of first wearing, changes according to the thermal conductivity, density and specific heat values of the material [17].

The thermal absorbtivity values of the fabrics are shown in figure 2. According to the data, the thermal absorbtivity values of the fabrics vary between 131 and $175 \mathrm{Ws}^{1 / 2} / \mathrm{m}^{2} \mathrm{~K}$. When the results are examined, the highest thermal absorbtivity values are in fabrics which are produced by cotton/acrylic and viscose weft yarns, in plain weave. This result means that this fabric will make feel cool, in the first contact with them. Among the experimental results, the lowest thermal absorbtivity value is in the fabrics which were woven by PES weft yarn, in twill and satin weave. When density of these fabrics is calculated taking into account the weight and thickness values, two fabrics have the lowest density value in terms of fabric density. One of the parameters affecting the thermal absorbtivity of the fabric is the fabric density. As the fabric density increases, the thermal absorbtivity value increases. In PES wefted fabrics, as the fabric density is lower, the thermal absorbtivity of fabrics is lower too.

When the graphic in figure 2 is examined, it is generally seen that the thermal absorbtivity values of fabrics woven in plain weave, are higher than the thermal absorbtivity values of fabrics woven in twill and satin weave. Accordingly, among fabrics woven by all weft types at a weft density of 17 threads/cm, it can be concluded that plain weave fabrics make feel colder than twill and satin fabrics.

When the thermal absorbtivity measurement results of the experimental fabrics are evaluated statistically (table 2), it is seen that the weave type has an effect on the thermal absorbtivity, the used weft type and the weft density have no effect on the thermal absorbtivity. According to the results of the Tukey test (table 3), it was seen that there was a meaningful difference between plain and twill and satin weave, but not a significant diference between twill and satin weave.

Air permeability $\left(1 / \mathrm{m}^{2} / \mathrm{sec}\right)$ is the quantity of passing air in unit time from unit area, under a certain pressure difference between two surfaces of a material. It describes the passing ability of air through the fiber, yarn and fabric structure. This parameter, which allows easier transfer of heat and determines the breathability feature, has an important place among the thermal comfort features [18]. Air permeability values of the experimental fabrics shown in figure 3 . Air permeability values vary between $89-440 \mathrm{l} / \mathrm{m}^{2} / \mathrm{s}$. When the graph is examined, it is seen that the highest air permeability value belongs to the satin weave fabric by PES weft yarn. The air permeability of fabrics is affected by the porosity of the fabrics. Fabrics with high porosity allow more air to pass through. When the porosity values of the fabrics woven by PES weft yarn are examined (table 1), it is seen that

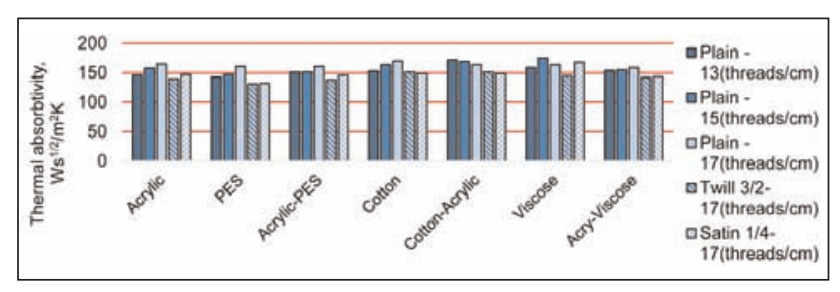

Fig. 2. Thermal absorbtivity values of the fabrics

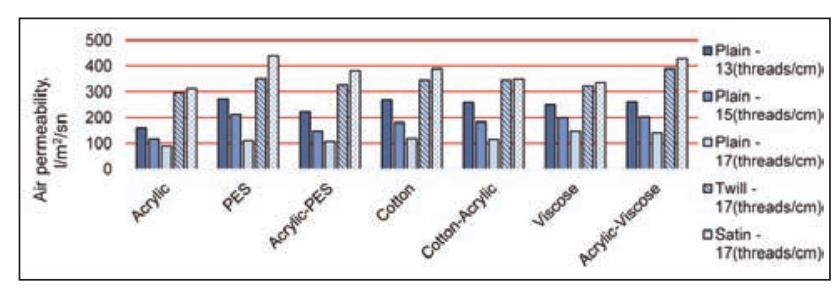

Fig. 3. Air permeability valuesof the fabrics 


\begin{tabular}{|c|c|c|c|c|c|}
\hline \multicolumn{6}{|c|}{$\begin{array}{l}\text { EFFECT OF WEFT DENSITY ON AIR PERMEABILITY, RESULTS OF THE MULTIPLE COMPARISON } \\
\text { (POST-HOC) TEST }\end{array}$} \\
\hline \multicolumn{6}{|c|}{ Multiple comparisons } \\
\hline \multirow{7}{*}{ Tukey HSD } & $\begin{array}{l}\text { Dependent } \\
\text { variable }\end{array}$ & (I) Weft density & (J) Weft density & $\begin{array}{l}\text { Mean difference } \\
(I-J)\end{array}$ & Sig. \\
\hline & \multirow{6}{*}{ Air permeability } & \multirow{2}{*}{13} & 17 & $124,2857^{*}$ & 0 \\
\hline & & & 15 & $67,5714^{*}$ & 0,002 \\
\hline & & \multirow{2}{*}{17} & 13 & $-124,2857^{*}$ & 0 \\
\hline & & & 15 & $-56,7143^{*}$ & 0,009 \\
\hline & & \multirow{2}{*}{15} & 13 & $-67,5714^{*}$ & 0,002 \\
\hline & & & 17 & $56,7143^{*}$ & 0,009 \\
\hline
\end{tabular}

they are the most porous fabrics together with the cotton fabrics.

According to figure 3, the fabric which was woven by acrylic weft yarn, in plain weave and at 17 threads $/ \mathrm{cm}$ weft density, has the lowest air permeability value. The porosity value of this fabric is lower than the porosity values of fabrics woven with other weft types. The low porosity of the fabric has reduced air permeability by making this fabric more resistant to air passage.

When the air permeability measurement results were statistically evaluated, it was found that the influence of the weft type used on fabrics on the air permeability was not significant but the weft density and the air permeability of the weave type were significant (table 2). The air permeability decreased as the weft density increased in plain weave fabrics. The reason for this is that as the weft density increases, the porosity of the fabric decreases. When the effect of the weft density on air permeability was examined statistically (table 4), as Sig. values are smaller than 0.05 , it can be said that there is a significant difference between all density values. When the effect of the applied weave type on the air permeability is examined, it is seen that the air permeability of the fabrics woven by plain weave is lower than the fabrics woven by twill and satin weave. Previous studies showed that fabrics woven with plain weave are more resistant to air passage than fabrics woven by other weaves with the same yarn count and densities. Hence, in our study, that the air permeability values of the fabrics woven with the twill and satin weaves are higher than the air permeability values of the fabrics woven with the plain weave, supports this result [18]. When the effect of the weave type on the air permeability was statistically analyzed (table 3 ), while the effect of the plain weave structure on the air permeability was statistically significant compared to the twill and satin weave, there was no statistically significant difference between the effect of the twill and satin weave air permeability.

Water vapour resistance (Ret) $\left(\mathrm{m}^{2} \mathrm{~Pa} / \mathrm{W}\right)$ is the resistance of the material to the flow of water vapour. It is the ratio of water vapour pressure difference between to surfaces of a material to heat flow in unit area in the direction of heat flow.
The relative water vapour permeability of a textile surface is expressed as the ability of vapour transferring formed by sweating from the body to the external environment. If the water vapour permeability of the fabric is low, so if the steam resistance is high, the heat stored in the body and consequently the sweat can't be removed ant that cause to an unpleasant sensation [19].

According to the results of the water vapour resistance measurements of the experimental fabrics (figure 4), the fabrics which have the lowest water vapour resistance are woven usingcotton and viscose weft yarn. The fabrics with the highest water vapour resistance are those woven with acrylic and PES weft yarn. This can be explained by lower porosity of acrylic weft fabrics and high porosity of cotton weft fabrics. On the other hand, PES and cotton weft fabrics and acrylic and viscose weft fabrics have porosity values very close to each other. But, PES weft fabrics have higher water vapour resistance compared to cotton weft fabrics and acrylic weft fabrics have higher water vapour resistance compared to viscose wetf fabrics. When available literature is examined on relative water vapour permeability (\%), contradicting results are encountered about effect of fabrics produced by hydrophobic and hydrophilic fibers on relative water vapour permeability (\%). Some of the researchers point out that hydrophilic fabrics increases relative water vapour permeability (\%) [20-22] while the others conclude that hydrophobic fabrics have higher relative water vapour permeability (\%) [23-25]. In this research, fabrics produced with hydrophilic weft yarns (viscose and cotton) show higher relative water vapour permeability velower water vapour resistance than fabrics produced with hydrophobic weft yarns (PES and acrylic). As a result type of fiber used in the production of fabrics had

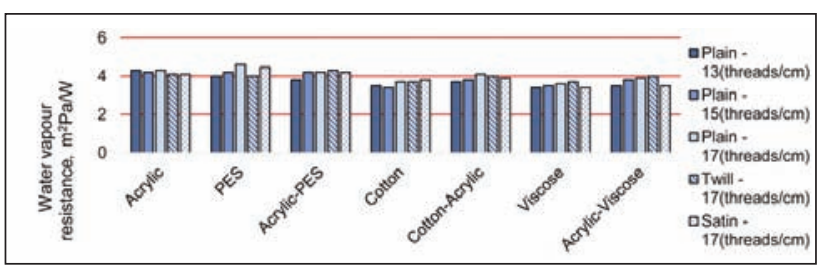

Fig. 4. Water vapour resistance values of the fabrics 
EFFECT OF WEFT TYPE ON WATER VAPOUR RESISTANCE, RESULTS OF THE MULTIPLE COMPARISON (POST-HOC) TESTS

\begin{tabular}{|c|c|c|c|c|c|c|c|c|c|}
\hline \multicolumn{10}{|c|}{ Multiple comparisons } \\
\hline \multirow[t]{2}{*}{ 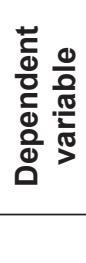 } & 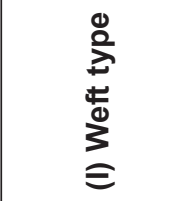 & 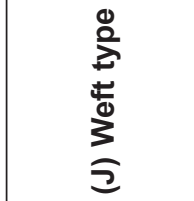 & 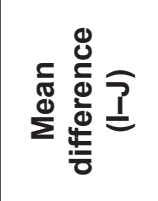 & क் & 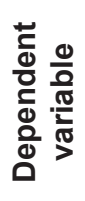 & 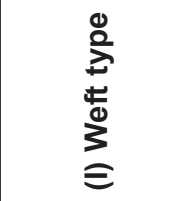 & 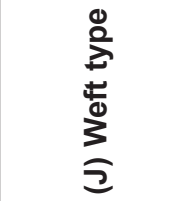 & 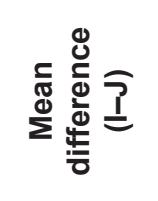 & $\frac{\dot{\theta}}{\dot{\infty}}$ \\
\hline & \multicolumn{4}{|c|}{ Tamhane } & & \multicolumn{4}{|c|}{ Tamhane } \\
\hline \multirow{24}{*}{ 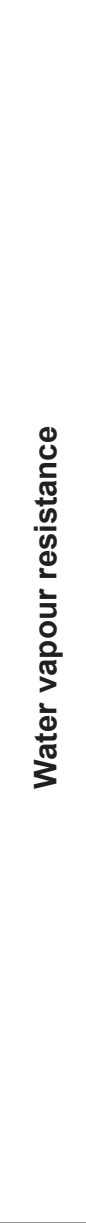 } & \multirow{6}{*}{ Acyrlic } & 1PES-1Acr & 0,06000 & 1,000 & \multirow{24}{*}{ 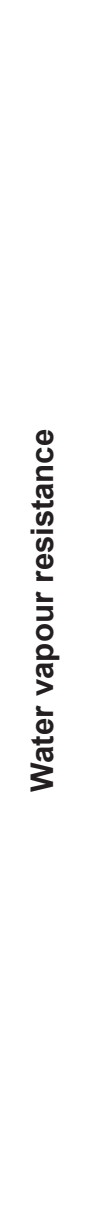 } & \multirow{6}{*}{ 1Co.-1Acr. } & Acrylic & $-0,30000$ & 0,181 \\
\hline & & PES & $-0,03400$ & 1,000 & & & 1PES-1Acr & $-0,24000$ & 0,764 \\
\hline & & Cotton & $0,58000^{*}$ & 0,007 & & & PES & $-0,33400$ & 0,552 \\
\hline & & 1Co-1Acr & 0,30000 & 0,181 & & & Cotton & 0,28000 & 0,416 \\
\hline & & Viscose & $0,68000^{*}$ & 0 & & & Viscose & 0,38000 & 0,071 \\
\hline & & 1Vis-1Acr & 0,46000 & 0,151 & & & 1Vis-1Acr & 0,16000 & 0,997 \\
\hline & \multirow{6}{*}{ 1PES-1Acr. } & Acrylic & $-0,06000$ & 1,000 & & \multirow{6}{*}{ Viscose } & Acrylic & $-0,68000^{*}$ & 0 \\
\hline & & PES & $-0,09400$ & 1,000 & & & 1PES-1Acr & $-0,62000^{*}$ & 0,012 \\
\hline & & Cotton & $0,52000^{*}$ & 0,041 & & & PES & $-0,71400^{*}$ & 0,023 \\
\hline & & 1Co.-1Acr & 0,24000 & 0,764 & & & Cotton & $-0,10000$ & 1,000 \\
\hline & & Viscose & $0,62000^{*}$ & 0,012 & & & 1Co-1Acr & $-0,38000$ & 0,071 \\
\hline & & 1Vis.-1Acr & 0,40000 & 0,325 & & & 1Vis.-1Acr & $-0,22000$ & 0,913 \\
\hline & \multirow{6}{*}{ PES } & Acrylic & 0,03400 & 0,000 & & \multirow{6}{*}{ 1Vis.-1Arc. } & Acrylic & $-0,46000$ & 0,151 \\
\hline & & 1PES-1Acr & 0,09400 & 1,000 & & & PES-Acr & $-0,40000$ & 0,325 \\
\hline & & Cotton & $0,61400^{*}$ & 0,046 & & & PES & $-0,49400$ & 0,207 \\
\hline & & 1Cot.-1Acr & 0,33400 & 0,552 & & & Cotton & 0,12000 & 1,000 \\
\hline & & Viscose & $0,71400^{*}$ & 0,023 & & & 1Co-1Acr & $-0,16000$ & 0,997 \\
\hline & & 1Vis.-1Acr & 0,49400 & 0,207 & & & Viscose & 0,22000 & 0,913 \\
\hline & \multirow{6}{*}{ Cotton } & Acrylic & $-0,58000^{*}$ & 0,007 & & & & & \\
\hline & & 1PES-1Acr & $-0,52000^{*}$ & 0,041 & & & & & \\
\hline & & PES & $-0,61400^{*}$ & 0,046 & & & & & \\
\hline & & 1Co.-1Acr & $-0,28000$ & 0,416 & & & & & \\
\hline & & Viscose & 0,10000 & 1,000 & & & & & \\
\hline & & 1Vis.-1Acr & $-0,12000$ & 1,000 & & & & & \\
\hline
\end{tabular}

effect on water vapour resistance more pronounced than fabric porosity in this study.

When the results ofwater vapour resistance are evaluated statistically, while the influence of the weft type used in fabrics on water vapour resistance was significant, the effect of the weft density and weave type on water vapour resistance is not found as significant (table 2). According to the multiple comparison (Tamhane) test presented in table 5 , it is seen that there is a statistical difference between water vapour resistance values of acrylic and cotton, as well as acrylic and viscose weft fabrics. There is no statistical difference in terms of water vapourresistance values between PES and acrylic weft fabrics.

\section{CONCLUSIONS}

In this study, the effects of acrylic yarns, which are not used in fine woven fabrics, on the thermo-physiological comfort properties of woven fabrics are investigated. For this purpose, woven fabrics have been produced by warp yarn acrylic and by weft yarns acrylic, PES, cotton, viscose, acrylic/PES, acrylic/cotton and acrylic/viscose at three different weft densities and weave structures. Thermal comfort, air permeability and water vapour resistance properties of woven fabrics have been tested.

The highest value of thermal resistance was observed on the woven fabric using twill weave with PES weft yarn. This fabric is the thickest of all experimental fabrics. The thermal resistance values of fabrics woven in twill and satin weaveswere higher than the thermal resistance of fabrics woven in plain weave. The reason for this is that the twill and satin weave fabrics are thicker than the fabrics woven in plain weave. When the thermal resistance measurement results are statistically evaluated, it is seen that the weave type has an effect on thermal resistance 
and weft type and weft density have no effect on thermal resistance. Moreover, it's found that there is a significant difference between plain weave and twill and satin weave but no significant difference between twill and satin weave.

Fabrics which were woven by cotton/acrylic and viscose weft yarns, in plain weave, had the highest thermal absorbtivity values and fabrics which were woven by PES weft yarn in twill and satin weave had the lowest thermal absorbtivity values. This means that in the first contact, cotton/acrylic and viscose weft fabrics will give a cool feeling, and PES weft fabrics will give a warm feeling. It is generally seen that the thermal absorbtivity values of fabrics woven in plain weave, are higher than those of fabrics woven in twill and satin weaves. Accordingly, among fabrics woven by all weft types, it can be concluded that plain weave fabrics make feel colder than twill and satin fabrics. When the results were evaluated statistically, it was found that the weave type had an effect on thermal absorbtivity, the weft type used and the weft density had no effect on thermal absorbtivity. In addition, the result is that plain weave fabrics give a colder feel than twill and satin fabrics.

Air permeability measurement results show that the highest air permeability value belongs to fabric woven by PES weft yarn and in satin weave and the lowest air permeability value belongs to fabric woven by acrylic weft yarn and in plain weave. Fabrics with high porosity allow more air to pass through. When the porosity values of the fabrics woven with PES weft yarn are considered, it is seen that they are the most porous fabrics together with the cotton fabrics. Porosity of acrylic weft fabrics is found to be lower than all the other fabrics. When the results are statistically evaluated, the effect of the weft type used on fabrics on air permeability was not significant but effect of the weft density and weave were significant. Furthermore, it has been found that air permeability of fabrics woven in plain weave is lower than that of fabrics woven in twill and satin weave.

The results of the water vapourresistancemeasurement; the fabrics woven by cotton weft yarn have the lowest water vapourresistance, the fabrics having the highest water vapourresistance; woven by acrylic weft yarn and in twill and satin weave. In the statistical evaluations, it was found that the effect of the weft type used in fabrics on thewater vapour resistance was significant and effect of the weft density and weave type were not significant.

\section{ACKNOWLEDGEMENT}

This research is financially supported by BAP Project (No: OUAP (MH)-2014/10), funded by Uludag University, Turkey.

\section{BIBLIOGRAPHY}

[1] Slater, K., The assesment of comfort, In: Journal of the Textile Institute, 1985, 77 (3), pp. 157-171

[2] Saville, B.P., Physical testing of textiles, Woodhead Publishing Limited, 2007, Cambridge, England

[3] Li, Y., The science of clothing comfort, In: Textile Progress, 2001, 31 (1-2), pp. 1-135

[4] Guanxiong, Q., Yuan, Z., Zhongwei, W., Jianli, L. \& Jie, Z., Comfort in knitted fabrics, In: International Man-Made Fibers Congress Proceeding, 1991, Portugal, pp. 34-38

[5] Behera, B. K. \& Mishra, R., Comfort properties of non-conventional light weight worsted suiting fabrics, In: Indian Journal of Fibre\& Textile Research, 2007, 32

[6] Mangat, M., M., The effect of moisture and finishing on thermal comfort and selected mechanical properties of denims with a portion of synthetic fibres, Ph.D. Research, Technical University, 2012, Liberec, Czech Republic

[7] Erenler, A.,Giysi amaçlı dokunmuş kumaşlarda konfor özelliklerinin incelenmesi ve tahminlenmesi, Çukurova Üniversitesi, Fen Bilimleri Enstitüsü, Tekstil Mühendisliği Anabilim Dalı, Doktora Tezi, 2013, Adana

[8] Li, M., Wu, Y., Chen, C. \& Du, Z., Characterization of planter press-comfort performance of warp-knitted spacer fabrics, In: Textile Recearch Journal, 2016, doi:10.1177/0040517516679152

[9] Unal, P.G. \& Ureyen, M.E., Mechanical and permeability properties of sportech fabrics, In: Industria Textila, 2016, 67(3), pp.151-156

[10] Akcagun, E., Yılmaz, A., Ö.Ceviz, N. \& Mazarı A., Investigating the thermal comfort properties of men's jacket as single and multiple layered material, In: Industria Textila, 2017, 68(6), pp. 458-463

[11] Hes, L., Araujo, M. \& Djulay, V., V. Effect of mutual bonding of textile layers on thermal insulation and thermal contact properties of fabric assemblies, In: Textile Research Journal, 1996, 66 (4), pp. 245-250

[12] Hes, L. \& Araujo, M., Simulationof the effect of air gaps between the skin and a wet fabric on resulting cooling flow, In: Textile Research Journal, 2010, 80 (14), pp. 1488-1497

[13] Turan, R. B., Kumaşların geçirgenlik özellikleri ile yapısal ve geometrik özellikleri arasındaki ilişkiler. Dokuz Eylül Üniversitesi, Fen Bilimleri Enstitüsü, Tekstil Mühendisliği Anabilim Dalı, Doktora Tezi, 2012, pp. 382

[14] Peirce, F. T., The geometry of cloth structure, In: Journal of the Textile Institute, 1937, 28(3), pp. 45-96

[15] Frydrych, I., Dziworska, G. \& Bilska, J., Comparative analyses of the thermal Insulation properties of fabrics made of natural and man-made cellulose fibres, In: Fibers \& Textiles in Eastern Europe, 2002, 10, pp. 40-44

[16] Kayri, M., Araştırmalarda gruplar arası farkın belirlenmesine yönelik çoklu karşılaştırma (post-hoc) teknikleri. Fırat Üniversitesi Sosyal Bilimler Dergisi, 2009, 19/1, pp. 51-64 
[17] Hes, L., Optimisation of shirt fabrics' composition from the point of view of their appearance and thermal comfort, In: International Journal of Clothing Science and Technology, 1999, 11 (2/3), pp. 105-115

[18] Backer, S., The relationship between the structural geometry of a textile fabric and its physical properties. Part IV: Interstice geometry and air permeability, In: Textile Research Journal, 1951, 21, pp. 703-714

[19] Ertekin, G. \& Marmaralı, A., Askı ve atlamanın düz örgü kumaşların ısıl konfor özelliklerine etkileri. In: Tekstilve Mühendis, 2011, 83, pp. 21-26

[20] Das, B., Das, A., Kothari, V., Fanguiero, R. \& Araujo, M., Moisture flow through blended fabrics-effect of hydrophilicity, In: Journal of Engineered Fibers and Fabrics, 2009, 4 (4), pp. 20-28

[21] Das, B., Das, A., Kothari, V.K., Fangueiro, R. \& Araujo, M., Studies on moisture transmission properties of PV-blended fabrics, In: The Journal of the Textile Institute, 2009, 100 (7), pp. 588-597

[22] Kandhavadivu, P., Ramachandran, T. \& Geetha Manohari, B., Moisture transmission behavior of micro fibre blended fabrics, In: Journal of Textile Association, 2011, 71 (6), pp. 311-315

[23] Knight, B., A., Hersh, S.P. \& Brown, P., Moisture characteristics of some knit fabrics made from blend yarns, In: Textile Research Journal,1970, 40 (9), pp. 843-851

[24] Hassan, M., Qashqary, K., Hassan, H.A., Shady, E. \& Alansary, M., Influence of sportswear fabric properties on the health, In: Fibres\& Textiles in Eastern Europe, 2012, 20 (4), pp. 82-88

[25] Varshney, R.K., Kothari, V.K. \& Dhamija, S., A study on thermophysiological comfort properties of fabrics in relation to constituent fibre fineness and cross-sectional shapes, In: Journal of the Textile Institute, 2010, 101 (6), pp. 495-505

\section{Authors:}

\section{ARZU YAVAŞCAOĞLU1 ${ }^{1}$, RECEP EREN² ${ }^{2}$ GÜLCAN SÜLE ${ }^{2}$}

${ }^{1}$ Yalova University, Yalova Vocational School, 77100, Yalova, Turkey e-mail: arzu.yavascaoglu@yalova.edu.tr

2Uludağ University, Faculty of Eng., Textile Eng. Department, 16059, Nilüfer, Bursa,Turkey e-mail: erecep@uludag.edu.tr, gulcan@uludag.edu.tr

Corresponding author:

\section{GÜLCAN SÜLE}

e-mail: gulcan@uludag.edu.tr 